\title{
REGISTRO ADMINISTRATIVO
}

\section{O Serviço de Administração do D.A.S.P. Tem Nôvo Diretor}

OMEÇANDo a compor o quadro dos novos diretores do Departamento Administrativo do Serviço Público, o Sr. Diretor-Geral recentemente nomeado empossou, no cargo dé Diretor do Serviço de Administração, o Sr. Joaquim Emygdio de Castro, exonerando-o, em decorrência, da função de Diretor da Revista do Serviço Pública.

A transmissão de cargo ocorreu no Gabinete do Sr. Wagner Estelita Campos, em Brasilia, às 11 horas do dia 10 de junho p.p., tendo usado da palavra o Sr. Diretor-Geral e o empossado.

Perde, assim, a R.S.P., o seu Diretor, ao mesmo tempo em que o S.A. ganha um nôvo chefe, afeito aos sérios problemas administrativos sob a jurisdição daquele Serviço, mercê de suas anteriores atividades públicas, inclusive de chefe do Serviço de Pessoal do Departamento de Imprensa Nacional. 